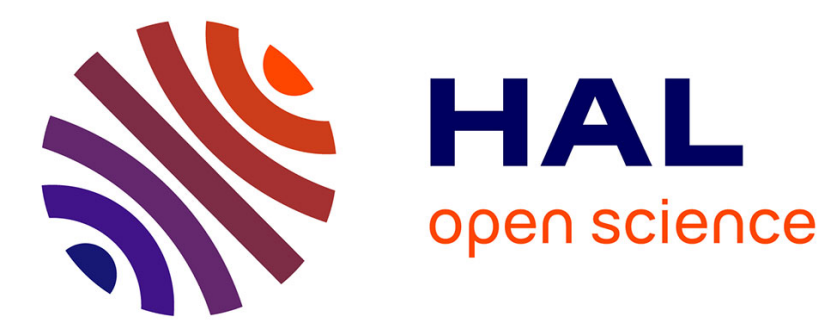

\title{
Revisiting the possible links between the Quasi-Biennial Oscillation and the Indian summer monsoon using NCEP R-2 and CMAP fields
}

\author{
Chantal Claud, Pascal Terray
}

\section{- To cite this version: \\ Chantal Claud, Pascal Terray. Revisiting the possible links between the Quasi-Biennial Oscillation and the Indian summer monsoon using NCEP R-2 and CMAP fields. Journal of Climate, 2007, 20, pp.773-787. 10.1175/JCLI4034.1 . hal-00162028}

\section{HAL Id: hal-00162028 \\ https://hal.science/hal-00162028}

Submitted on 22 Jun 2016

HAL is a multi-disciplinary open access archive for the deposit and dissemination of scientific research documents, whether they are published or not. The documents may come from teaching and research institutions in France or abroad, or from public or private research centers.
L'archive ouverte pluridisciplinaire HAL, est destinée au dépôt et à la diffusion de documents scientifiques de niveau recherche, publiés ou non, émanant des établissements d'enseignement et de recherche français ou étrangers, des laboratoires publics ou privés. 
Revisiting the possible links between the Quasi-Biennial Oscillation and the Indian summer monsoon using NCEP R-2 and CMAP fields

Chantal Claud $^{1}$ and Pascal Terray ${ }^{2,3}$

(1) LMD/IPSL, Ecole Polytechnique, Palaiseau, France

(2) LOCEAN/IPSL, Paris, France

(3) Université Paris 7, Paris, France

Journal of Climate

Revised version

May 2006 


\section{Abstract}

In the past the stratospheric Quasi-Biennial Oscillation (QBO) has sometimes been proposed to explain the tendency for the Indian Summer Monsoon (ISM) to alternate between strong and weak years. In this study, NCEP Reanalysis-2 and CMAP fields are statistically analyzed to assess the relationship between equatorial zonal winds in the stratosphere and ISM. In a first step, it is shown that zonal winds at $15 \mathrm{hPa}$ during the preceding winter (January-February) are the best stratospheric predictor of the summer rainfall over the Indian subcontinent as a whole. This relationship mainly holds for August and September, or the late ISM. Surprisingly, the QBO pattern is not significantly associated with the rainfall variability during June-July or the early ISM. CMAP and NCEP R-2 fields corroborate these findings and show that westerly QBO years are associated with a deepening of the monsoon trough over the Gangetic plains and decreased convective activity in the eastern equatorial Indian region. However, further statistical analysis shows that the QBO-ISM link is complex since a westerly QBO phase at 15 $\mathrm{hPa}$ in boreal winter leads to a weaker monsoon surface circulation with, in particular, a weakening of the Somali Jet at the beginning of the monsoon, but a much stronger circulation in September. At that time, the Tibetan High is reinforced, the tropical easterly jet at $200 \mathrm{hPa}$ is stronger over India and the local reversed Hadley circulation is also strengthened north of the equator. The mechanisms by which the QBO may affect ISM have been explored through in particular correlations between stratospheric winds and tropopause temperature and pressure fields. Our results provide support for an out of phase behavior of convective activity between the Indian sub-continent and the equatorial Indian Ocean induced by the QBO phase, especially during the late ISM. During a westerly QBO phase, convective activity is, in September, enhanced over India, which brings higher precipitation, compared to the east phase. This work 
also suggests that the winter QBO at $15 \mathrm{hPa}$ could have some skill in foreshadowing the late ISM. 


\section{Introduction}

The existence of a biennial component in tropospheric climatic variables and, in particular, in the Asian summer monsoon rainfall and various El-Niño Southern Oscillation (ENSO) indices is well known (e.g. Mooley and Parthasarathy, 1984; Tian and Yasunari, 1992; Shen and Lau, 1995; Kane, 1992, 1995; Terray, 1995; Meehl, 1987, 1993, 1997; Barnett, 1991; Rasmusson et al., 1990; Ropelewski et al., 1992; among many others). More specifically, the presence of a biennial signal in the Indian Summer Monsoon (ISM) rainfall has been reported by numerous workers (e.g. Mooley and Parthasarathy, 1984; Kane, 1992, 1995; Terray, 1995).

According to Meehl (1993), the tendency for the monsoon system to alternate often between strong and weak years could be attributed to large-scale coupled land-ocean-atmospheric interactions in the Indian and Pacific Ocean regions. Alternatively, several authors have suggested that the existence of biennial tropospheric signals may stem from regional coupled ocean-atmosphere processes in the Indo-Pacific warm pool areas (Nicholls, 1979; Clarke and Shu, 2000; Clarke et al., 1998; Chang and Li, 2000; Li et al., 2001). Goswami (1995) has also proposed a conceptual model explaining how strong intraseasonal oscillations, such as the Madden-Julian oscillation, interacting with the annual cycle may produce a strong biennial signal in the atmosphere and how the ocean-atmosphere coupling may subsequently produce a weak biennial signal in the ocean. Finally, a few authors have suggested the stratospheric Quasi-Biennial Oscillation (QBO) as an explanation for these tropospheric biennial signals (Yasunari, 1989; Gray et al., 1992). The QBO in the mean zonal wind is the dominant feature of the tropical stratosphere in the height range of $18-50 \mathrm{~km}$ or $70-10 \mathrm{hPa}$ pressure range (Baldwin et al., 2001). It consists of zonally symmetric regimes of easterly and westerly winds, which descend through the middle and lower stratosphere at a rate of about $1 \mathrm{~km}$ per month (Figure 1). The peak-to-peak range is about $42 \mathrm{~m} / \mathrm{s}$ at the Equator and decreases symmetrically away from it with a half width of about $12^{\circ}$ latitude. There is a preferred arrival of QBO shear 
zones in the lower stratosphere at the end of northern summer (Dunkerton and Delisi, 1985; Huesmann and Hitchman, 2001). Using zonal wind data at $50 \mathrm{hPa}$ from Singapore $\left(1.4^{\circ} \mathrm{N}\right.$, $\left.140^{\circ} \mathrm{E}\right)$, Korur $\left(7.3^{\circ} \mathrm{N}, 134.5^{\circ} \mathrm{E}\right)$ and Ponape $\left(7^{\circ} \mathrm{N}, 158.2^{\circ} \mathrm{E}\right)$, Yasunari (1989) suggested that a coherent phase structure exists between the lower stratospheric zonal wind (QBO) and biennial oscillations large-scale zonal wind anomalies in the lower and upper troposphere. He also showed that the QBO in the lower stratosphere is coupled with Sea Surface Temperatures (SST) in equatorial Pacific regions. However, other studies have suggested that the tropospheric biennial signal and the stratospheric QBO are only weakly related in a statistical sense because the tropospheric biennial signal is tightly phase-locked to the seasonal cycle, its phase occasionally reverses and its period ( 24 months) is shorter than the mean QBO period (Quiroz, 1983; Barnett, 1991; Xu, 1992). Nevertheless, Gray et al. (1992) argued that this weak statistical relationship should not be interpreted as a lack of a physical interaction between the QBO and the coupled monsoon-ENSO system since the modulation of atmospheric circulations with a strong seasonal cycle by the QBO may produce biennial tropospheric signals similar to those described by the above studies. Furthermore, Baldwin et al. (2001) does not exclude the fact that the QBO may influence the underlying tropical troposphere, but with an effect occurring at certain times and places.

In recent years, numerous Indian scientists have reported a link between the stratospheric zonal winds and ISM and, in particular, with the Indian Monsoon Rainfall (IMR), so that the QBO is now recognized as an important factor for foreshadowing the ISM (Thapliyal and Kulshrestha, 1992; Rajeevan et al., 2004). Mukherjee et al. (1979) found that a strong easterly phase of the QBO was associated with a weak ISM. On the other hand, Thapliyal (1984) showed that the January circulation features at $50 \mathrm{hPa}$ can be indicative of deficient (normal) IMR in westerly (easterly) QBO years. Mukherjee et al. (1985) found a significant correlation between the IMR and mean zonal wind for June-August at $30 \mathrm{hPa}$ level using wind data for Balboa $\left(9^{\circ} \mathrm{N}, 80^{\circ} \mathrm{W}\right)$ 
for the period 1951-1982. Bhalme et al. (1987) related the January $10 \mathrm{hPa}$ zonal wind anomalies and the IMR and found a correlation larger than 0.5 during the period 1958-1985, with the IMR tending to be less (more) than normal during an easterly (westerly) anomaly. Furthermore, these authors argued that floods never occur with easterly phase of the QBO while droughts are unlikely during a westerly phase of the QBO. Khandekar (1996) suggested that the occurrence of strong and weak ISMs can be explained by three independent factors: ENSO, Eurasian snow cover, and the QBO. This author proposed a conceptual model for drought or flood years in the Indian monsoon based on the magnitudes and phases of these three factors and argued that the QBO is the primary factor driving the biennial component of ISM interannual variability (Khandekar, 1998). More recently, Chattopadhyay and Bhatla (2002) showed that the QBO may explain the different behavior of the ISM in ENSO years: easterly phases of QBO at $50 \mathrm{hPa}$ during the monsoon season associated to ENSO events are likely to cause droughts, while westerly QBO phases are likely to result in a normal monsoon. More globally, in a study based on interannual variations of Outgoing Longwave Radiation (OLR) in the tropics during 1975-1987, Collimore et al. (1998) found that deep convection is enhanced in some areas when 50-70 hPa QBO westward shear exists in the lower stratosphere, and diminished during eastward shear. Using a longer record, Collimore et al. (2003) have confirmed that the frequency and horizontal extent of convection fluctuates with the QBO.

From a modeling point of view, the influence of the phase of the stratospheric QBO on monsoon interannual variability has been studied in sensitivity experiments in which the easterly or westerly phase of the QBO is imposed in the model by relaxation of the zonal winds in the lower stratosphere to observed structures (Giorgetta et al., 1999). Simulations suggest that the monsoon is stronger during the westerly phase (taken at $50 \mathrm{hPa}$ ) of the QBO and weaker during the easterly phase. In addition, the model results support the hypothesis that the mechanism behind this association is primarily through changes in the lower stratospheric 
vertical circulation which affects the height of the tropopause and hence the depth of convection.

In spite of this pervasive evidence of a relationship between the variability of the ISM and the QBO, there is still controversy on this issue. As an illustration, it must be emphasized that the IMR time series is not basically biennial as it is often assumed, but rather exhibits a triennial oscillation as many monsoon indicators (Bhalme and Jadhav, 1984). Recently, Fasullo (2004) has also questioned the existence of a biennial component in ISM variability. Furthermore, the stratospheric QBO may not be necessary to explain observed tropospheric biennial variability in the Indian sector as pointed out by Terray (1998). It is also pertinent to note that some of the earlier studies on the ISM-QBO relationships obtained quite different results (Kripalani and Kulkarni, 1997a) and that the QBO-ISM association lacks a reasonable cause-effect mechanism validated by observations.

Hence, there is a real need to explore again the ISM-QBO relationships using more recent datasets. The existence of the so-called reanalyses, which consist in long global records of data, enables to reconsider the question of the association between equatorial stratospheric winds and ISM. It must be kept in mind that such an association, if any, would be particularly important for the long-range forecasting of ISM. In this paper, we carry out a statistical analysis of the NCEP R-2 data (Kanamitsu et al., 2002). We employ the monthly mean data covering the period 1979-2000, thus encompassing about 10 QBO cycles. Although data exist over a longer period for the previous NCEP-NCAR reanalysis (Kalnay et al., 1996), we choose to use only the second reanalysis R-2 period, since it is considered as more reliable for at least two reasons: first, many of the known problems found in the earlier reanalysis have been corrected and secondly, use is made of satellite data for the whole period (possible shifts due to their use or not are therefore avoided). A similar work using the first reanalysis over the period 1948-2001 produced similar, but weaker and less significant results. 
The paper is organized as follows. The data sources and statistical methodology are briefly described in Section 2. In Section 3, correlations between zonal winds in the stratosphere and IMR are first discussed; then, the tropospheric signatures of the QBO associated with ISM atmospheric circulation are presented. Finally the results from the analysis are summarized and discussed in section 4 .

\section{Data and method}

The IMR index chosen in this study is the All India Rainfall Index, as defined by Parthasarathy et al. (1995). This series has been prepared by area-weighting 306 well-distributed raingauges over the plains regions of India. This rainfall time series has been shown to be the most accurate measure of rainfall over the Indian subcontinent (Annamalai et al., 1999). For completeness, global precipitation fields called CMAP (Climate Prediction Center Merged Analysis Precipitation, Xie and Arkin, 1996, 1997) have also been considered. CMAP is a gridded global monthly precipitation constructed on a 2.5 × 2.5 degree latitude/longitude grid, covering the period from 1979 until 2001. It relies on gauge observations and on estimates of precipitation inferred from microwave and infrared satellite observations.

Mean equatorial zonal winds for levels between 70 and $10 \mathrm{hPa}$, which characterize the QBO, were obtained from the Free University of Berlin (Naujokat, 1986 ; http://strat-www.met.fuberlin.de) from 1953 on (1956 for the $10 \mathrm{hPa}$ level).

For the characterization of the links between QBO and the monsoon, use was made of the NCEP R-2 reanalysis data (Kanamitsu et al., 2002). Monthly means from January 1979 through December 2001 are available at 12 levels from 1000 to $100 \mathrm{hPa}$. Data are given on a $2.5 \times 2.5$ degree latitude/longitude grid. Winds at 850 and $200 \mathrm{hPa}$ have been considered to characterize the monsoon surface and upper-level circulation, respectively. The $500 \mathrm{hPa}$ vertical velocity (w) is used to describe the areas of deep convection, and the $200 \mathrm{hPa}$ geopotential heights 
provides additional information about the upper-level dynamical situation. For addressing the issue of the mechanisms involved in the $\mathrm{QBO} /$ monsoon relationships, temperature at various stratospheric levels (from 10 to $100 \mathrm{hPa}$ ) has also been considered.

In order to highlight the space-time structure of the monsoon and the QBO-ISM links, standard lead-lag cross-correlation and regression techniques between the stratospheric winds and atmospheric fields have been performed. Due to the well-defined spectral signature of the stratospheric zonal wind, the statistical significance of the results has been assessed with a phase-scrambling bootstrap test with 999 samples (Davison and Hinkley, 1997). This type of test takes directly into account the autocorrelation characteristics of the time series under investigation and is thus more appropriate than a conventional Student $t$ test.

\section{Results}

a-Correlation between monthly zonal winds in the stratosphere and monsoon rainfall

In a preliminary step, a systematic correlation analysis has been carried out using IMR and mean equatorial stratospheric zonal winds (Naujokat, 1986) taken at 7 different levels and for 8 months either preceding or covering the summer monsoon period for 1953-2001 (1956-2001 at $10 \mathrm{hPa}$ ). The objective is twofold: first, check if there is a significant correlation between these two terms and second, choose the most adequate level and time lead to perform further statistical analyses. As a matter of fact, in previous studies, at least three different levels and distinct time leads have been considered, and the choice has never been really justified by the various authors (e.g. Thapliyal, 1984; Mukherjee et al., 1985; Bhalme et al., 1987; Kane, 1995). The correlation coefficients of the IMR index and stratospheric zonal winds are listed in Table 1 , but only when their significance is larger than the $90 \%$ confidence level according to the phase-scrambling bootstrap test described in the previous section. In spite of a rather weak relationship, the largest correlations, reaching 0.38 , are obtained when considering the 
stratospheric zonal winds from January-February at $15 \mathrm{hPa}$. Westerlies (i.e. eastward, hereafter "west phase") at 15-20 hPa during January-February correspond to increased rainfall for the following ISM, compared to easterlies. Correlations are slightly larger $(0,4$ for January and 0,381 for February) when restricting the analysis to the period after 1979, but in this latter case, they are slightly less significant (94 and 93\%, respectively). The sign and amplitude of these correlations are in agreement with an earlier study by Bhalme et al. (1987). Interestingly, this positive correlation remains significant during March and April, but the maximum in April (0.33) is now noted at $20 \mathrm{hPa}$. During the period of the monsoon itself, the highest correlation is obtained when considering 30 and $40 \mathrm{hPa}$ levels. This significant and systematic propagation of positive correlations across different levels may be useful for the explanation of the physical mechanisms underlying the QBO-IMR association and is consistent with the downward phase propagation of the QBO (Baldwin et al., 2001).

The ISM exhibits considerable intraseasonal variability. However, analysis of observations indicate that strong and weak ISMs are significantly linked to persistent rainfall and large-scale circulation anomalies during August and September or the late ISM and that physical processes sustaining ISM interannual variability are somewhat different during the early (June-July) and late (August-September) ISM (Ailikun and Yasunari, 2001; Terray et al., 2003). An illustration is provided by the correlations between the early and late IMR time series during both the 1948-2001 and 1979-2000 periods, which are only 0.26 and 0.15 , respectively. These two correlation coefficients are not significant at the $90 \%$ confidence level. This interesting result confirms a very early study by Mooley (1971) and motivated additional correlation analyses of early and late IMR indices with the stratospheric zonal wind time series. Correlations between early IMR time series and the stratospheric zonal winds are never significant at the $90 \%$ confidence level whatever time lead or level is selected (not shown). On the other hand, the statistics for the late IMR index support the previous results for the whole ISM (values in italics 
in Table 1). In addition, at $15 \mathrm{hPa}$, correlation coefficients are larger when considering only the late IMR and their significance also increases with a confidence level of $99 \%$ from January to April before the ISM onset. The correlations also gain significance for the other levels during the monsoon. Thus, these results suggest that the whole ISM will be stronger (weaker) during west (east) QBO years, but that this statistical relationship is largely controlled by rainfall and circulation anomalies of August and September, or the late ISM. This intriguing aspect of the QBO-ISM relationship deserves further study in the next section.

Due to the meridional fluctuations of the axis of the monsoon trough, the ISM also exhibits considerable spatial variability. Thus, the distribution of ISM rainfall over the Indian subcontinent varies largely from one region to another. Moreover, large precipitation over the Indian Ocean, and particularly, over the Bay of Bengal, cannot be ignored in the definition of ISM (Goswami et al., 1999). To illustrate more precisely the relationship between the QBO phase and the spatial variability of ISM rainfall, Figure 2 shows correlations between the QBO index and CMAP rainfall fields during the monsoon season for the 1979-2000 period. In agreement with Table 1, a positive correlation (e.g. increased rainfall during westerly QBO years) is observed over central and north India. In addition, the Bay of Bengal is characterized by a positive correlation, and the Arabian Sea by a negative correlation. Interestingly, the significant positive correlation area observed in Figure 2 corresponds to the axis of the monsoon trough which is normally oriented along the Gangetic Valley and is a key-feature of the monsoon system (Mukherjee et al., 1985; Terray, 1995). Since the rainfall in the Gangetic plains is mainly associated with the frequency and strength of traveling monsoon disturbances coming from the Bay of Bengal, this result may suggest that the number and/or intensity of these disturbances are also correlated to the phase of the QBO. Sikder et al. (1993) also found that the east phase of the QBO decreases depression activity in the Bay of Bengal and along the axis of the monsoon trough. 
Finally, several studies have shown the existence of two favorable locations for the Inter Tropical Convergence Zone (ITCZ) during boreal summer, one over the Indian subcontinent and the second over the eastern equatorial Indian Ocean (Sikka and Gadgil, 1980; Krishnan et al., 2003). Furthermore, it is known that there is an out of phase relationships between the convective activity at these two favorable locations, the active phases of one ITCZ coinciding with the weak phases of the other at the intraseasonal time scale (Yasunari, 1981; Kripalani et al., 1991,1992,1996). Based on these results, the significant negative correlations observed in the eastern equatorial Indian Ocean and the significant positive correlations over the IndoGangetic plains in Figure 2 suggest that the overall impact of the westerly phase of the QBO will be to inhibit the convective activity associated with the equatorial ITCZ over the Indian Ocean and to strengthen the off-equatorial convection associated with the monsoon trough.

\section{b.Evolution of $Q B O$ related atmospheric circulation anomalies}

Keeping in mind the significant QBO-IMR relationship, an attempt is made in the present section to identify the atmospheric circulation patterns associated with the QBO during the monsoon season. From the preceding results, it was decided that the index for performing further statistical analyses would be zonal winds at $15 \mathrm{hPa}$ during January-February. As a consequence, correlation and regression patterns between the mean equatorial zonal wind at 15 $\mathrm{hPa}$ in January-February and the NCEP-R2 reanalysed $850 \mathrm{hPa}$ wind and $500 \mathrm{hPa}$ vertical velocity fields for each month of the summer monsoon have been determined for the period 1979-2000 (Figure 4). However, prior to discussing the influence of the QBO phase on the atmospheric circulation, a similar analysis, but using the IMR, is presented on Figure 3. In both figures, the $500 \mathrm{hPa}$ vertical velocity (w) anomalies have been superimposed on the $850 \mathrm{hPa}$ wind regression patterns in order to describe vertical motion. Note that areas characterized by negative (positive) $500 \mathrm{hPa}$ vertical velocity anomalies correspond to anomalous ascent 
(subsidence) and increased (decreased) convection. Moreover, only features that exhibit correlations exceeding the 90\% confidence level are displayed in Figures 3 and 4.

Figure 3 emphasizes the regions and monthly circulation features associated with large ISM rainfall anomalies. At the surface, an enhancement of the monsoon low-level gyre circulation is observed during both the early (e.g. July) and late (e.g. September) ISM. In July, the Somali Jet and the zonal wind over the Arabian Sea are strengthened, however the significant (at the $90 \%$ confidence level) negative $500 \mathrm{hPa}$ omega anomalies (anomalous ascent) over the Indian subcontinent are restricted to a small area, northwest of India and Pakistan. The most significant surface and upper-level circulation anomalies with respect to the cumulated seasonal rainfall for India as a whole occur during September. During this month, large and significant negative $500 \mathrm{hPa}$ vertical velocity anomalies are observed along the axis of the monsoon trough in the Gangetic plains (Figure 3d). Consistent with these negative omega anomalies, reflecting an enhancement of the rainfall activity (Figure 2), the anomalous surface atmospheric circulation observed during September shows the intensity of the lower tropospheric vorticity anomalies associated with the Rossby wave response to the ISM trough and convective heating (Wang et al., 2001). In agreement with earlier findings of Terray et al. (2003), broad-scale and significant anomalous circulation patterns are also observed in the South Indian Ocean during this particular month. Over this area, the regression maps for September suggests a westward shift of the Mascarene High which is consistent with a strengthening of the monsoon circulation (Terray et al., 2003).

The influence of the QBO phase on the surface ISM circulation is illustrated in Figure 4. These regression patterns may be compared with those derived from the IMR index. At the beginning of the monsoon, in June (Figure 4a), a significant impact is observed in the western Indian Ocean, with a west phase of the $\mathrm{QBO}$ at $15 \mathrm{hPa}$ in February-March leading to anomalous ascent to the east and southeast of Madagascar and, thus, a weakening of the Mascarene High. 
In agreement with this feature, the cross-equatorial flow into the western Arabian Sea is significantly reduced. This may be interpreted as a delayed ISM onset or a weak early ISM. However, both the $850 \mathrm{hPa}$ wind and $500 \mathrm{hPa}$ omega anomalies are rather small over the Indian subcontinent during June. Moreover, the wind pattern is somewhat different from the wind regression pattern derived from the IMR time series (Figure 3a). In July and August (Figures $4 \mathrm{bc})$, the QBO effect over the Indian areas is small, except perhaps in July in the eastern Arabian Sea where westerly (easterly) surface zonal wind anomalies are associated with a west (east) phase of the QBO. Finally, in September, the association between the phase of the QBO and the ISM atmospheric circulation reaches a maximum and gains high significance (Figure 4d). There are negative omega values (anomalous ascent) over the Indian subcontinent and positive omega values in the southwest subtropical Indian Ocean, both features suggesting a strong late ISM. Furthermore, the anomalous circulation pattern suggests a significant strengthening of the low-level circulation with a westward shift of the Mascarene High in the south Indian Ocean and a deeper ISM trough over the Indian subcontinent (Figure 4d). All these characteristics are associated with a strong ISM. As a matter of fact, the Mascarene High shift has been shown to be associated with a strengthening of the monsoon circulation through a modulation of the local Hadley cell during the late ISM and therefore also constitutes a favorable environment for a stronger monsoon (Terray et al., 2003). Overall, the structures of the QBO regression patterns in Figure 4d have striking resemblances to the September regression patterns derived from the IMR time series (Figure 3d). From a quantitative point of view, Figure $4 \mathrm{~d}$ indicates that the effects on $850 \mathrm{hPa}$ winds does not exceed $0,1 \mathrm{~m} / \mathrm{s}$ for a change of $1 \mathrm{~m} / \mathrm{s}$ in stratospheric winds at $15 \mathrm{hPa}$ in January-February. However, the winds at 15 $\mathrm{hPa}$ in January-February exhibit a standard deviation of almost $20 \mathrm{~m} / \mathrm{s}$, which leads to a change of $850 \mathrm{hPa}$ wind speed of $2 \mathrm{~m} / \mathrm{s}$, which is not negligible. 
To assess the effect of the QBO on the upper-level circulation, regressions have also been calculated for the $200 \mathrm{hPa}$ wind and $200 \mathrm{hPa}$ geopotential height (Figure 5). The $200 \mathrm{hPa}$ geopotential heights regression coefficients are displayed in color shading with the $200 \mathrm{hPa}$ wind regression patterns. Once again, it is in September (Figure 5d) that the effect is the more striking and significant: the Tibetan High is found more pronounced and shifted westward during westerly QBO years, which leads to an enhanced anticyclonic circulation and a stronger tropical easterly jet over the Indian subcontinent at $200 \mathrm{hPa}$. Furthermore, the upper branch of the local (reversed) Hadley circulation between central India and the equatorial Indian Ocean is significantly strengthened during September of west QBO years (Figure 5d). This is consistent with the north-south seesaw of convective activity over the Indian sector depicted in Figure 2. As for the surface circulation, significant upper wind and geopotential height anomalies are also observed in the southern Indian Ocean with a decrease of $200 \mathrm{hPa}$ geopotential heights to the east of Australia and an associated cyclonic circulation. This also suggests that the Mascarene High is shifted westward during westerly QBO years. In other words, the whole upper late ISM circulation seems anomalously enhanced (reduced) during westerly (easterly) QBO years. Interestingly, there is no appreciable effect of the QBO on the equatorial Indian Ocean $200 \mathrm{hPa}$ zonal wind and geopotential height (Figure 5d). This is in contradiction with one aspect of the hypothetical mechanism proposed by Gray et al., 1992, (e.g. their figure 6) or Khandekar (1996) which is based on the premise that an anomalous downward "bulge" is imposed on the upper tropospheric surface near the Equator during the westerly QBO years. Alternatively, Giorgetta et al. (1999) have proposed a mechanism in which the QBO's secondary meridional circulation creates temperature anomalies down to the tropopause, which implies a change of static stability, and consequently a modulation of convective activity leading to a modified monsoon intensity. Since then, an idealized General Circulation Model (GCM) experiment conducted by Thuburn and Craig (2000) showed that changes in the 
stratospheric meridional circulation modify the vertical profile of the cumulus heating in the upper troposphere and the tropopause height.

Therefore, we have also analyzed the relationship between the temperature at different atmospheric levels and the QBO (Figure 6). In addition, a similar study has been conducted for the tropopause temperature and pressure for the period 1979-2000 as provided by the first NCEP-NCAR reanalysis (Kalnay et al., 1996), since there is no tropopause file in the second NCEP R-2 reanalysis (Figures 7 and 8). The tropopause definition is based on the standard lapse rate criterion and previous studies have shown that, in spite of a warm time-constant bias of the analyzed tropopause temperature compared to radiosoundings, its seasonal cycle as well as interannual variability is reasonable in the NCEP-NCAR reanalysis for the period 1979-2000 (Randel et al., 2000). As expected and independently of the stratospheric level which is considered, the QBO effect on the stratospheric temperatures consists of a positive zonal anomaly along the Equator along with a negative one in the subtropics in the second NCEP reanalysis (not shown). Interestingly, this anomalous temperature gradient is still observed at the $100 \mathrm{hPa}$ level (in the NCEP R-2 data) which has often been used as a proxy for the tropopause. This anomalous temperature gradient is particularly significant during July and September (Figures 6bd). For completeness, we also present the correlation analysis with the "explicit" tropopause temperature from the NCEP-NCAR reanalysis in Figure 7. Consistent with Figure 6, the QBO effect is manifested as a warmer tropopause over the Equator and a colder one in the subtropics in the first NCEP reanalysis (Figure 7). Moreover, a careful analysis of the results indicates again that this out of phase behavior is particularly prominent in July and September, with large positive significant correlations over the equatorial Indian Ocean, and large negative significant values over Asia (Figures 7bd). In a consistent way, the tropopause pressure is larger (i.e. lower tropopause) close to the Equator compared to the Indian subcontinent (i.e. higher tropopause) as shown in Figures 8bd. This suggests that the 
convective activity during the west phase of the QBO is therefore enhanced over central and northern India at that time of the year compared to the equatorial Indian Ocean, and this brings higher precipitation over India and less precipitation along the Equator (Figure 2). As already mentioned in Section 3a, such a feature is well known at the intraseasonal time scale during the summer monsoon (e.g. Yasunari, 1981; Krishnan et al., 2003). We therefore speculate that the QBO influences the monsoon by modulating the upwelling, thus producing a north-south seesaw of convective activity between the Indian subcontinent and the equatorial Indian Ocean. It is in September (and to a certain extent in July), that this out-of-phase behavior is the strongest; during a westerly QBO phase, convection is enhanced over the subcontinent, and this may explain the higher precipitation, compared to an easterly QBO phase (Figure 2).

Since cross-tropopause shear variations have also been proposed for a possible mechanism for linking the QBO to deep convection (e.g. Collimore et al., 2003), correlations between the QBO phase and the wind shear between 150 and $70 \mathrm{hPa}$ have been calculated. It must be noted that a west phase in winter at $15 \mathrm{hPa}$ corresponds to a west shear in the low stratosphere during the monsoon season. A west phase of the QBO corresponds to an increased cross-tropopause wind shear over the equatorial Indian Ocean in July-August-September (i.e. less favorable for convection), but this signature is not statistically significant (not shown). Decreased wind shear is observed over Asia in July and September, but it is only significant at the $90 \%$ level in July. This shear mechanism can therefore not be totally ruled out as complementing the mechanism described in the preceding paragraph, but it is probably not the prominent one to explain the links between the QBO and the Indian summer monsoon.

Finally, some studies have shown correlations between the monsoon intensity and Eurasian snow cover extent or depth (e.g. Hahn and Shukla, 1976, Yang et al., 1996). Since there are quasi-biennial variations in snow depth over northern Eurasia (Ye, 2000, $2001 \mathrm{a}$ and b), it would be tempting to relate QBO, snow and monsoon. These variations have been shown to be 
associated with SST anomalies over the central North Pacific and tropical western Atlantic extending into the Gulf of Mexico (Ye, 2000, $2001 \mathrm{a}$ and b). The atmospheric circulation patterns that bridge this connection are the EU-1 (Eurasian Pattern 1, Barnston and Livezey, 1987) and the PNA (Pacific-North America). On the other hand, the snow cover (or depth) anomalies over the Asian continent during boreal spring have been thought to have a significant impact on the interannual variations of the ISM through the so-called "snow-hydrological effect" (Yasunari et al., 1991; Vernekar et al., 1995). However, an important unresolved problem for the snow cover-ISM relation is how the winter or spring snow cover anomaly is "transmitted" to the following summer. Thus, the physical mechanism through wich Eurasian snow influences the ISM is not well understood. Besides, the observational evidence of the Eurasian snow-monsoon connection is not robust, with at times contradictory results (e.g. Robock et al. 2003 found a positive correlation while several other studies report a negative correlation). Finally, the fact that the QBO-ISM rainfall correlation is especially significant during the late ISM contradicts the hypothesis that the QBO influence on ISM is realized through potential modulation of Eurasian winter snow cover extent/depth since in that case the QBO signal should be particularly strong in the early phase of ISM.

\section{Discussion and conclusion}

In this observational study, the association between the characteristics of ISM and the winds in the stratosphere has been investigated, using a statistical analysis. First, correlations between IMR and zonal winds at different stratospheric levels and for different months have been calculated over the period 1953-2001 to infer which level and time lead were the most appropriate to carry out more detailed statistics. As a matter of fact, previous studies have considered at least three different levels and distinct time lead. Zonal winds at $15 \mathrm{hPa}$ during January-February were found to have the largest and most significant correlation with IMR. 
Furthermore, a systematic propagation of positive and significant correlations across different levels is observed from the boreal winter to boreal summer which is consistent with the downward propagation of the QBO. A second original result is that the correlation is increased and more significant if only August-September rainfall is considered, and that it is therefore important to distinguish between the early and late phases of the monsoon when trying to look at the impact of the stratosphere on it. This emphasizes the specific role played by the late ISM to explain the interannual variability of the monsoon (Terray et al., 2003). In addition, results remain globally unchanged if only the period after 1979 is considered, unlike other connections like the ISM-ENSO relationship which have a more intermittent nature (e.g. Kripalani and Kulkarni, 1997b,c; Kinter et al., 2002).

In a second step, atmospheric fields (precipitation, winds, vertical velocity, geopotential height) have been analyzed according to the phase of the QBO in order to identify the atmospheric patterns associated with each phase. A contrasted, but consistent in space and time over the variables, effect of the phase of the QBO on monsoon circulation has been observed. A westerly phase of QBO at $15 \mathrm{hPa}$ in January-February is associated in June with a decrease of the surface circulation and, in particular, a weaker Somali Jet, which suggests a delayed ISM onset. Conversely, in September, the monsoon surface circulation is significantly reinforced during the west phase of the QBO, which means a positive precipitation anomaly over central India and a deepening of the monsoon trough. In addition to this "direct" effect, anomalous and significant circulation patterns are also observed in the southern Indian Ocean during the late ISM according to the phase of the QBO: the Mascarene High is stronger and shifted westward during the west phase of the QBO. Interestingly, this shift has been shown to be associated with an enhancement of the monsoon circulation through a modulation of the inter-hemispheric Hadley cell during the late ISM and therefore means a stronger monsoon (Terray et al., 2003). Likewise, at $200 \mathrm{hPa}$, this is also in September that the effect of the QBO is the strongest, with 
a reinforcement of the Tibetan High over northern India and a strengthening of the upper branch of the local Hadley cell linking the monsoon trough and the equatorial Indian Ocean. While it is well known that in the Indian sector, a double ITCZ structure is frequently observed during boreal summer with an out of phase relationship between the two convective zones, this last result suggests that a west phase of the QBO influences the monsoon activity by enhancing the upward motion over the Indian subcontinent and inhibiting it over the eastern equatorial Indian Ocean, thus producing a north-south seesaw of convective activity in the Indian sector.

To address in more details the question of the mechanisms responsible for the QBO-related monsoon variability, similar correlations have been calculated considering stratospheric temperature and tropopause temperature and pressure fields. During a west QBO phase, stratospheric temperatures are larger along the Equator but smaller in the subtropics; this is still true at the tropopause level, with a warmer and lower tropopause along the Equator, compared to the subtropics. This is in September that the opposition between the equatorial Indian Ocean and the Indian subcontinent is the strongest; at that time, as a consequence of the lower tropopause level, a west QBO phase may alter deep convective activity along the Equator, and, conversely, enhance convection over India. This brings higher precipitation over the subcontinent compared to an east QBO phase. This mechanism is consistent with most of our observations (precipitation, winds, geopotential heights). The vertical velocity at $500 \mathrm{hPa}$ in September (Figure 4d) shows clearly the increased upwelling over the Indian continent but not a significant decrease of the convection along the Equator; a careful analysis of the results however reveals that this area is just below the $90 \%$ significant level. Given that there is a preferred arrival of QBO shear zones in the lower stratosphere at the end of northern summer that may also contribute to the early/late monsoon dichotomy, correlations between the QBO phase and cross-tropopause wind shears have been calculated. Increased shear, which is less favorable for convection, is observed over the Equator during the west phase while some areas 
over Asia experience a decreased shear. Results are however not statistically significant, which suggests that the shear mechanism only complements the mechanism proposed above.

These results are important to the predictability of ISM rainfall, particularly during the late ISM, since they suggest that the dominant mode of ISM during August and September is partly forced by the phase of the QBO (Terray et al., 2003). Results presented here indicate that the knowledge of the equatorial stratospheric winds during boreal winter can have a modest, but significant, predictive value on IMR forecast, since their effect is mostly during the months when the rainfall standard deviations are the largest (Terray et al., 2003). It is interesting to note that among the predictors used by the India Meteorological Department for operational long-range forecasting, and in spite of a revamping of their models in 2003, stratospheric wind pattern in winter is still used (Gowariker et al., 1991; Thapliyal and Kulshrestha, 1992, Rajeevan et al., 2004). The present study provides some evidence of the benefit of such an information.

For the future, it would be interesting to confirm these results using an alternative dataset such as the ERA-40 reanalysis. Further investigation on the role of the QBO on the number and intensity of traveling monsoon depressions originating in the Bay of Bengal has to be conducted. In addition, other effects of the stratosphere like the Arctic Oscillation (Gong and Ho, 2003) and the solar cycle (van Loon et al., 2004) on ISM need to be more precisely studied. Another important point concerns the possible impact of ENSO and the QBO-ENSO interactions. Previous studies on the ISM-ENSO relationship have shown that a majority of warm episodes in the central and eastern equatorial Pacific are accompanied by below-normal summer rainfall over India. The situation is reversed during cold events. These precipitation changes are associated with well-defined circulation features over the monsoon regions: dry conditions have been shown to coincide with low-level anticyclonic anomalies, and vice versa (Lau and Nath, 2000). Kripalani and Kulkarni (1997a) and Kripalani et al., 1999, who have 
reported significant correlations between $50 \mathrm{hPa}$ geopotential heights in the northern hemisphere in March and IMR, found that these correlations decreased if the ENSO years are excluded in the analysis. While we have checked that this is not the case for the results presented here, we think that there is a need to reinvestigate very carefully the QBO-ENSOISM interactions. Finally, in conjunction with observational studies, modeling efforts focusing on the interplay between these essential components of the monsoon system will be a valuable pathway to explain the complex interactions between the QBO and the ISM.

\section{Acknowledgments}

This work was supported by the French Programme National d'Etude Du Climat (PNEDC) through the VIMA project. Stratospheric equatorial zonal winds were obtained from the Free University of Berlin (http://strat-www.met.fu-berlin.de). The NCEP-NCAR reanalyses and CMAP datasets were provided by the NOAA Climate Center (http://www.cdc.noaa.gov) through ClimServ. Thanks are due to B. Duchiron for his assistance in data analysis and S. Masson for providing graphical software (SAXO) for plotting the results. 


\section{References}

Ailikun, B., and T. Yasunari, 2001: ENSO and Asian summer monsoon: persistence and transitivity in the seasonal march. J. Meteorol. Soc. Jpn, 79, 145-159.

Annamalai, H., J.M. Slingo, K.R. Sperber, and K. Hodges, 1999: The mean evolution and variability of the Asian summer monsoon: comparison of ECMWF and NCEP/NCAR reanalysis. Mon. Weather Rev., 127, 1157-1186.

Baldwin, M. P., L. J. Gray, K. Hamilton, P. H. Haynes, W. J. Randel, J. R. Holton, M. J. Alexander, I. Hirota, T. Horinouchi, D. B. A. Jones, J. S. Kinnersely, C. Marquardt, K. Sato, and M. Takahashi, 2001: The Quasi-biennial oscillation. Rev. Geophys., 39, 2, 179229.

Barnett, T.P., 1991: The interaction of multiple time scales in the tropical climate system. $J$. Climate, 4, 269-285.

Barnston, A.G. and R.E. Livezey, 1987 : Classification, seasonality and persistence of lowfrequency atmospheric circulation patterns, Mon. Wea. Rev., 115, 1083-1126.

Bhalme, H.N., and S.K. Jadhav, 1984: The Southern Oscillation and relation to the monsoon rainfall. J. Climatol., 4, 509-520.

Bhalme, H.N., S.S. Rahalkar and A.B. Sikdar, 1987: Tropical Quasi-Biennial Oscillation of the $10 \mathrm{mb}$ Wind and Indian Monsoon Rainfall. Implication for forecasting. J. Climatol., 7, $345-353$.

Chang, C.-P., and T. Li, 2000: A theory of the tropical tropospheric biennial oscillation. $J$. Atmos. Sci., 57, 2209-2224.

Chattopadhyay, J., and R. Bhatla, 2002: Possible influence of QBO on teleconnections relating Indian summer monsoon rainfall and sea-surface temperature anomalies across the Equatorial Pacific. Int. J. Climatol., 22, 121-127. 
Clarke A.J., X. Liu, and S. van Gorder, 1998: Dynamics of the biennial oscillation in the equatorial Indian and far western Pacific Oceans. J. Climate, 11, 987-1001.

Clarke A.J., and L. Shu, 2000: Quasi-biennial winds in the far western equatorial Pacific phaselocking El Nino to the seasonal cycle. Geophys. Res. Lett., 27, 771-774.

Collimore, C.C., M.H. Hitchman, and D.W. Martin, 1998: Is there a quasi-biennial oscillation in tropical deep convection? Geophys. Res. Letters, 25, 333-336.

Collimore, C.C., D.W. Martin, M.H. Hitchman, A. Huesmann, and D.E. Waliser, 2003 : On the relationship between the QBO and Tropical Deep Convection. J. Climate, 16, 2552-2568.

Davison, A.C., and D.V. Hinkley, 1997 : Bootstrap Methods and their Application, Cambridge University Press, 582 pp.

Dunkerton, T.J., and D.P. Delisi, 1985 : Climatology of the equatorial lower stratosphere, $J$. Atmos. Sci., 42, 376-396.

Fasullo, J., 2004 : Biennial characteristics of Indian Monsoon Rainfall. J. Climate, 17, 29722982.

Giorgetta, M.A., L. Bengtsson, and K. Arpe, 1999 : An investigation of QBO signals in the east Asian and Indian monsoon in GCM esperiments. Climate Dyn., 15, 435-450.

Gong, D.Y. and C.H. Ho, 2003: Arctic Oscillation signals in the East Asian summer monsoon. J. Geophys. Res., 108 (D2), 4066, doi:10.1029/2002JD002193.

Goswami, B.N., 1995 :A multiscale interaction model for the origin of the tropospheric QBO. J. Climate, 8, 524-534.

Goswami, B.N., V. Krishnamurty, and H. Annamalai, 1999: A broad-scale circulation index for the interannual variability of the Indian summer monsoon. Q.J.R. Meteor. Soc, 125, 611633. 
Gowariker, V., V. Thapliyal, S.M. Kulshrestha, G.S. Mandal, N. Sen Roy, and D.R. Sikka, 1991: a power regression model for long range forecast of southwest monsoon rainfall over India. Mausam, 42, 125-130.

Gray, W.M., J.D. Scheaffer, and J.A. Knaff, 1992 : Influence of the stratospheric QBO on ENSO variability. J. Meteorol. Soc. Jpn, 70, 975-995.

Hahn, D., and J. Shukla, 1976: An apparent relationship between Eurasian snow cover and Indian monsoon rainfall, J. Atmos. Sci., 33, 2461-2462.

Huesmann, A.S., and M.H. Hitchman, 2001 : The stratospheric quasi-biennial oscillation in the NCEP reanalyses: Climatological studies, J. Geophys. Res., 106 (D11), 11859-11874.

Kalnay, E., and Coauthors, 1996: The NCEP/NAR 40-year reanalysis project. Bull. Amer. Meteor. Soc., 77, 437-471.

Kanamitsu, M., W. Ebisuzaki, J. Woolen, S.K. Yand, J.J. Hnilo, M. Fiorino, and G.L. Potter, 2002: NCEP-DOE AMIP-II Reanalysis (R-2). Bull. Am. Meteorol. Soc., 83, 1631-1643.

Kane, R.P., 1992: Relationship between QBO's of stratospheric winds, ENSO variability and other atmospheric parameters. Int. J. Climatol., 12, 435-447.

Kane, R.P., 1995: Quasi-biennial and quasi-triennial oscillations in the summer monsoon rainfall of the meteorological Subdivisions of India. Mon. Weather Review, 123, 11781184.

Khandekar, M.L., 1996: El Niño/Southern Oscillation, Indian monsoon and world grain yieldsA synthesis. Land-based and Marine Hazards, M.I. El-Sabh et al., Eds., Advances in Natural and Technological Hazards Research, Vol. 7, Kluwer Academic, 79-95.

Khandekar, M.L., 1998: Comments on "Space-time structure of monsoon interannual variability. J. Climate, 11, 3057-3059.

Kinter, J.L., K. Miyakoda, and S. Yang, 2002: Recent change in the connection from the Asian Monsoon to ENSO. J. Climate, 15, 1203-1215. 
Kripalani, R.H., S.V. Singh, and P.A. Arkin,1991: Large-scale features of rainfall and OLR over Indian and adjoining regions. Contributions to Atmospheric Physics, 64,159-168.

Kripalani, R.H., S.V. Singh, A.D. Vernekar and V. Thapliyal, 1996: Empirical study on Nimbus-7 snow mass and Indian summer monsoon rainfall. International Journal of Climatology 16, 23-34.

Kripalani, R.H., and A. Kulkarni, 1997a: Possible link between the stratosphere and the Indian Monsoon Rainfall, SPARC Newsletter, 9, pp 21-22.

Kripalani R.H., and A. Kulkarni, 1997b: Climatic impact of El Nino/La Nina on the Indian Monsoon: A new perspective. Weather 52, 39-46.

Kripalani R.H., and A. Kulkarni, 1997c: Rainfall variability over Southeast Asia-connections with Indian Monsoon and ENSO extremes: New Perspectives. International Journal of Climatology 17, 1155-1168.

Kripalani R.H., A. Kulkarni, S.R. Inamdar, and K.D. Prasad, 1999: Teleconnections: Northern Hemisphere lower stratospheric geopotential heights and Indian monsoon rainfall. Meteorology and Atmospheric Physics, 69, 195-203.

Kripalani R.H., A. Kulkarni, and S.V. Singh, 1992: Classification of summer monsoon rainfall patterns over India. International Journal of Climatology, 12, 269-280.

Krishnan, R., M. Mujumdar, V. Vaidya, K.V. Ramesh, and V. Satyan, 2003: The Abnormal Indian Summer Monsoon of 2000, J. Climate, 16, 1177-1194.

Lau, K.M., and M.J. Nath, 2000: Impact of ENSO on the variability of the Asian-Australian monsoons as simulated in GCM experiments, J. Climate, 13, 4287-4309.

Li, T., C.-W. Tham, and C.-P. Chang, 2001: A coupled air-sea-monsoon oscillator for the tropospheric biennial oscillation. J. Climate, 14, 752-764.

Meehl, G.A., 1987 : The annual cycle and interannual variability in the tropical Pacific and Indian Ocean regions. Mon. Wea. Rev, 115, 27-49. 
Meehl, G.A., 1993 : A coupled air-sea biennial mechanism in in the tropical Indian and Pacific regions: Role of the ocean. J. Climate, 6, 31-41.

Meehl, G.A., 1997 : The south Asian monsoon and the tropospheric biennial oscillation. $J$. Climate, 10, 1921-1943.

Mooley, D.A., 1971: Independence of monthly and bi-monthly rainfall over Southeast Asia during the summer monsoon season. Mon. Wea. Rev, 99, 532-236.

Mooley, D.A., and B. Parthasarathy, 1984: Fluctuations in all-India summer monsoon rainfall during 1871-1978. Climat. Chang., 6, 287-301.

Mukherjee, B.K., R.S. Reddy, and Bh. V. Ramanamurty, 1979: High-level warmings, winds and Indian summer monsoon. Mon Wea. Rev., 107, 1581-1588.

Mukherjee, B.K., K. Indira., R.S. Reddy, and Bh. V. Ramanamurty, 1985: Quasi-biennial oscillation in stratospheric wind and Indian monsoon. Mon Wea. Rev., 113, 1421-1430.

Naujokat, B., 1986: An update of the observed Quasi-Biennial Oscillation of the stratospheric winds over the tropics. J. Atmos. Sci., 43, 1873-1877.

Nicholls, N., 1979: A simple air-sea interaction model. Quart. J. Roy. Meteor. Soc., 105, 93105

Parthasarathy, B., A.A. Munot, and D.R. Kothawale, 1995: All India monthly and seasonal rainfall series: 1871-1993. Theor. Appl. Climatolog., 49, 217-224.

Quiroz, R.S., 1983 : Relationships among the stratospheric and tropospheric zonal flows and the Southern Oscillation, Mon. Weather Rev., 111, 143-154.

Rajeevan, M., D. Pai, S.K. Dikshit, and R.R. Kelkar, 2004: IMD's new operational models for LRF of SW Monsoon rainfall over India and their verification for 2003. Current Science, 86, 422-431. 
Randel W.J., F. Wu, and D.J. Gaffen, 2000 : Interannual variability of the tropical tropopause derived from radiosonde data and NCEP reanalyses. J. Geophys. Res., 105 (D12), 1550915523.

Rasmusson, E. M., X. Wang, and C. F. Ropelewski, 1990: The biennial component of ENSO variability. J. Mar. Syst., 1, 71-90.

Robock, A., M.Q. Mu, K. Vinnikov, and D. Robinson, 2003 : Land surface conditions over Eurasia and Indian summer monsoon rainfall, J. Geophys. Res., 108 (D4), doi :10.1029/2002JD002286.

Ropolewski, C.F., and M.S. Halpert, and X. Wang, 1992: Observed tropospheric biennial variability and its relationship to the Southern Oscillation. J. Climate, 5, 594-614.

Shen, S., and K.M. Lau, 1995: Biennial oscillation associated with the east Asian monsoon and tropical sea surface temperatures, J. Meteorol. Soc. Jpn, 73, 105-123.

Sikder, A.B., S.K. Patwardhan and H.N. Bhalme, 1993: Tropical stratospheric circulation and monsoon rainfall. Advances in Atmospheric sciences, 10, 379-385.

Sikka, D.R., and S. Gadgil, 1980: On the maximum cloud zone and the ITCZ over the Indian longitudes during the Southwest Monsoon. Monthly Weather Review,108, 1840-1853.

Terray, P., 1995 : Space/time structure of monsoons interannual variability. J. Climate, 8, 25952619.

Terray, P., 1998 : Answer to Comments on "Space/time structure of monsoons interannual variability". J. Climate, 11, 3060-3061.

Terray, P., P. Delecluse, S. Labattu, and L. Terray, 2003: Sea Surface temperature associations with the late summer monsoon. Climate Dyn., 21, 593-618.

Thapliyal, V., 1984: Prediction of Indian droughts with lower stratospheric winds. Mausam, 35, $367-374$. 
Thapliyal, V., and S.M. Kulshrestha, 1992: Recent models for long-range forecasting of southwest monsoon rainfall over India. Mausam, 43, 239-248.

Thuburn, J. and G.C. Craig, 2000 : Stratospheric influence on tropopause height: The radiative constraint. J. Atmos. Sci., 57, 17-28.

Tian, S.F., and T. Yasunari, 1992: Time and space structure of interannual variations in summer rainfall over China. J. Meteorol. Soc. Jpn, 70, 585-596.

Van Loon, H., G.A. Meehl, and J.M. Arblaster, 2004: A decadal solar effect in the tropics in July-August. J. Atmos. Sol. Terr. Phys., 66, 1767-1778.

Vernekar, A.D., J. Zhou, and J. Shukla, 1995: The effect of Eurasian snow cover on the Indian monsoon. J. Climate, 8, 248-266.

Wang, B., R. Wu, and K.M Lau, 2001: Interannual variability of the Asian Summer Monsoon: contrasts between the Indian and the western North Pacific-east Asian monsoons. J. Clim, 14, 4073-4090.

Xie, P., and P.A. Arkin, 1996: Analyses of Global Monthly Precipitation Using Gauge Observations, Satellite Estimates, and Numerical Model Predictions. J. Climate, 9, 840858.

Xie, P., and P.A. Arkin, 1997: Global Precipitation: A 17-Year Monthly Analysis Based on Gauge Observations, Satellite Estimates and Numerical Model Outputs. Bull. Am. Meteorol. Soc., 78, 2539-2558.

Xu, J.S., 1992: On the relationship between the stratospheric quasi-biennial oscillation and the tropospheric Southern Oscillation. J. Atmos. Sci., 49, 725-734.

Yang, S., K.M. Lau, and M.S. Rao, 1996: Precursory signal associated with the interannual variability of the Asian summer monsoon, J. Climate, 9, 949-964.

Yasunari, T., 1981: Structure of an Indian summer monsoon system with around 40-day period, J. Meteorol. Soc. Jpn, 59, 336-354. 
Yasunari,T., 1989: A possible link of QBOs between the stratosphere, troposphere and sea surface temperature in the tropics. J. Meteorol. Soc. Jpn, 67, 483-493.

Yasunari, T., A. Kitoh and T. Tokioka, 1991: Local and remore responses to excessive snow mass over Eurasia appearing in the northern spring and summer climate - A study with the MRI GCM. J. Meteorol. Soc. Japan, 69, 473-487.

Ye, H., 2000 : Decadal variability of Russian winter snow accumulation and its associations with Atlantic sea surface temperature anomalies, Int. J. Climatol., 20, 1709-1728.

Ye, H., 2001 : Characteristics of winter precipitation variation over northern central Eurasia and their connections to sea surface temperatures over the Atlantic and Pacific Oceans, J. Climate, 14, 3140-3155.

Ye, H., 2001 : Quasi-Biennial and Quasi-Decadal variations in snow accumulation over northern Eurasia and their connections to the Atlantic and Pacific Oceans, J. Climate, 14, 4573-4584. 


\section{Figure captions}

Figure 1. Time-height section of monthly mean zonal winds $(\mathrm{m} / \mathrm{s})$ at Singapore $\left(1^{\circ} \mathrm{N}, 104^{\circ} \mathrm{E}\right)$. Isolepths are at $10 \mathrm{~m} / \mathrm{s}$ intervals; westerlies are shaded (updated from Naujokat, 1986).

Figure 2. Distribution of correlation coefficients of June-September CMAP precipitation versus equatorial zonal winds at $15 \mathrm{hPa}$ in January-February. Correlation coefficients have been computed for the 1979-2000 period. Correlation coefficients above the $90 \%$ confidence level following a phase-scrambling procedure with 999 samples are shaded. See text for more details.

Figure 3. Distribution of monthly regression coefficients of NCEP-R2 $850 \mathrm{hPa}$ wind and 500 hPa vertical velocity versus IMR in a) June, b) July, c) August, d) September. Regression coefficients have been computed for the 1979-2000 period. Maps only show wind vectors and omega values corresponding to regression coefficients above the $90 \%$ confidence level following a phase-scrambling procedure with 999 samples. See text for more details.

Figure 4. Distribution of monthly regression coefficients of NCEP-R2 $850 \mathrm{hPa}$ wind and 500 $\mathrm{hPa}$ vertical velocity versus equatorial zonal winds at $15 \mathrm{hPa}$ in January-February for a) June, b) July, c) August, d) September. Regression coefficients have been computed for the 19792000 period. Maps only show wind vectors and omega values corresponding to regression coefficients above the $90 \%$ confidence level following a phase-scrambling procedure with 999 samples. See text for more details. 
Figure 5. Same as Figure 4, but for the NCEP-R2 $200 \mathrm{hPa}$ wind and geopotential height versus equatorial zonal winds at $15 \mathrm{hPa}$ in January-February.

Figure 6. Distribution of monthly correlation coefficients of NCEP-R2 $100 \mathrm{hPa}$ temperature versus equatorial zonal winds at $15 \mathrm{hPa}$ in January-February for a) June, b) July, c) August, d) September. Correlation coefficients have been computed for the 1979-2000 period. Correlation coefficients above the $90 \%$ confidence level following a phase-scrambling procedure with 999 samples are shaded. See text for more details.

Figure 7. Distribution of monthly correlation coefficients of NCEP tropopause temperature versus equatorial zonal winds at $15 \mathrm{hPa}$ in January-February for a) June, b) July, c) August, d) September. Coefficients have been computed for the 1979-2000 period. Areas with correlation coefficients above the $90 \%$ confidence level following a phase-scrambling procedure with 999 samples are shaded. See text for more details.

Figure 8. Same as Figure 7, but for the NCEP tropopause pressure versus equatorial zonal winds at $15 \mathrm{hPa}$ in January-February. 


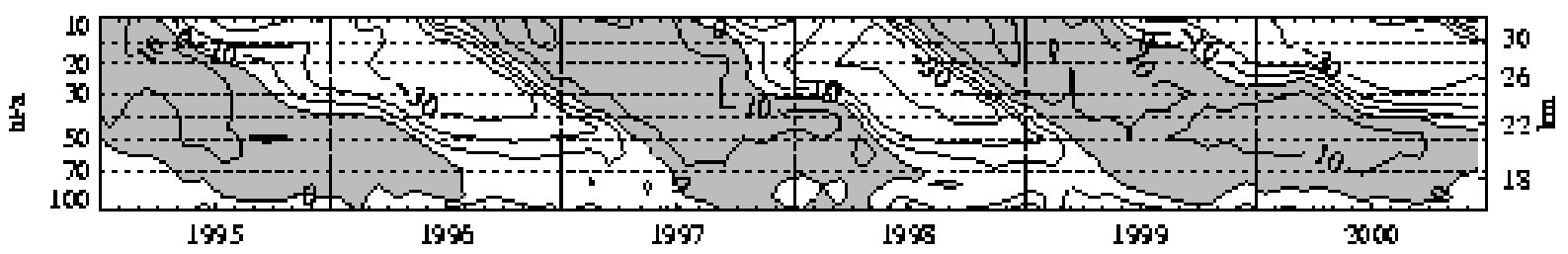

Figure 1. Time-height section of monthly mean zonal winds $(\mathrm{m} / \mathrm{s})$ at Singapore $\left(1^{\circ} \mathrm{N}, 104^{\circ} \mathrm{E}\right)$.

Isolepths are at $10 \mathrm{~m} / \mathrm{s}$ intervals; westerlies are shaded (updated from Naujokat, 1986). 
Correlations QBO $15 \mathrm{hPa}$ (1-2) Rainfall - CMAP dataset 1979-2000 -

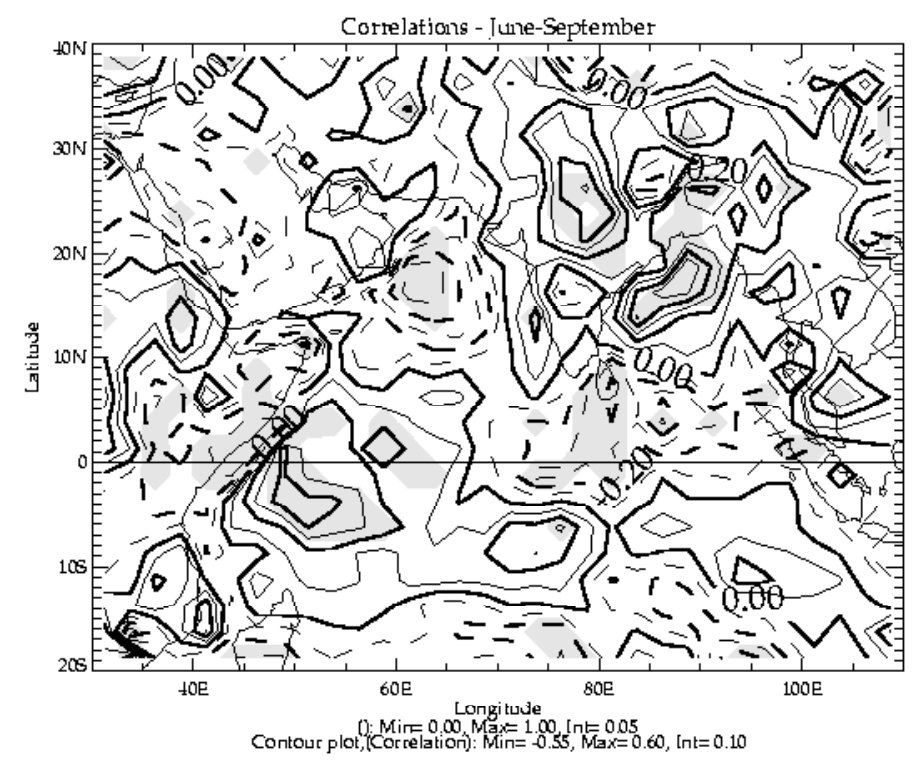

Figure 2. Distribution of correlation coefficients of June-September CMAP precipitation versus equatorial zonal winds at $15 \mathrm{hPa}$ in January-February. Correlation coefficients have been computed for the $1979-2000$ period. Correlation coefficients above the $90 \%$ confidence level following a phase-scrambling procedure with 999 samples are shaded. See text for more details. 
Regressions ISM rainfall (6-9) $850 \mathrm{hPa}$ wind/500 hPa Omega - NCEP2 1979-2000 -

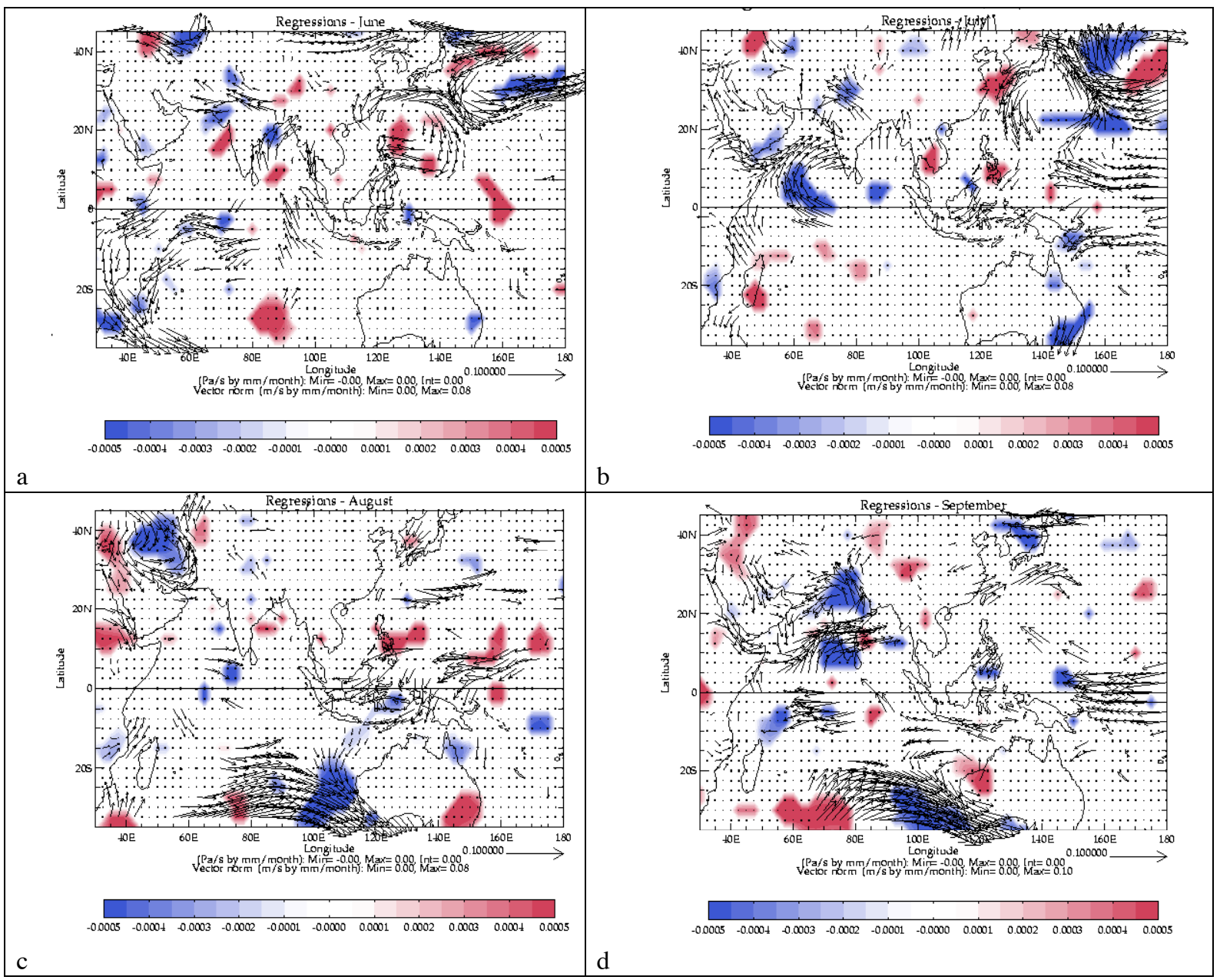

Figure 3. Distribution of monthly regression coefficients of NCEP-R2 $850 \mathrm{hPa}$ wind and 500 hPa vertical velocity versus IMR in a) June, b) July, c) August, d) September. Regression coefficients have been computed for the 1979-2000 period. Maps only show wind vectors and omega values corresponding to regression coefficients above the $90 \%$ confidence level following a phase-scrambling procedure with 999 samples. See text for more details. 
Regressions QBO $15 \mathrm{hPa}$ (1-2) $850 \mathrm{hPa}$ wind/500 hPa Omega - NCEP2 1979-2000

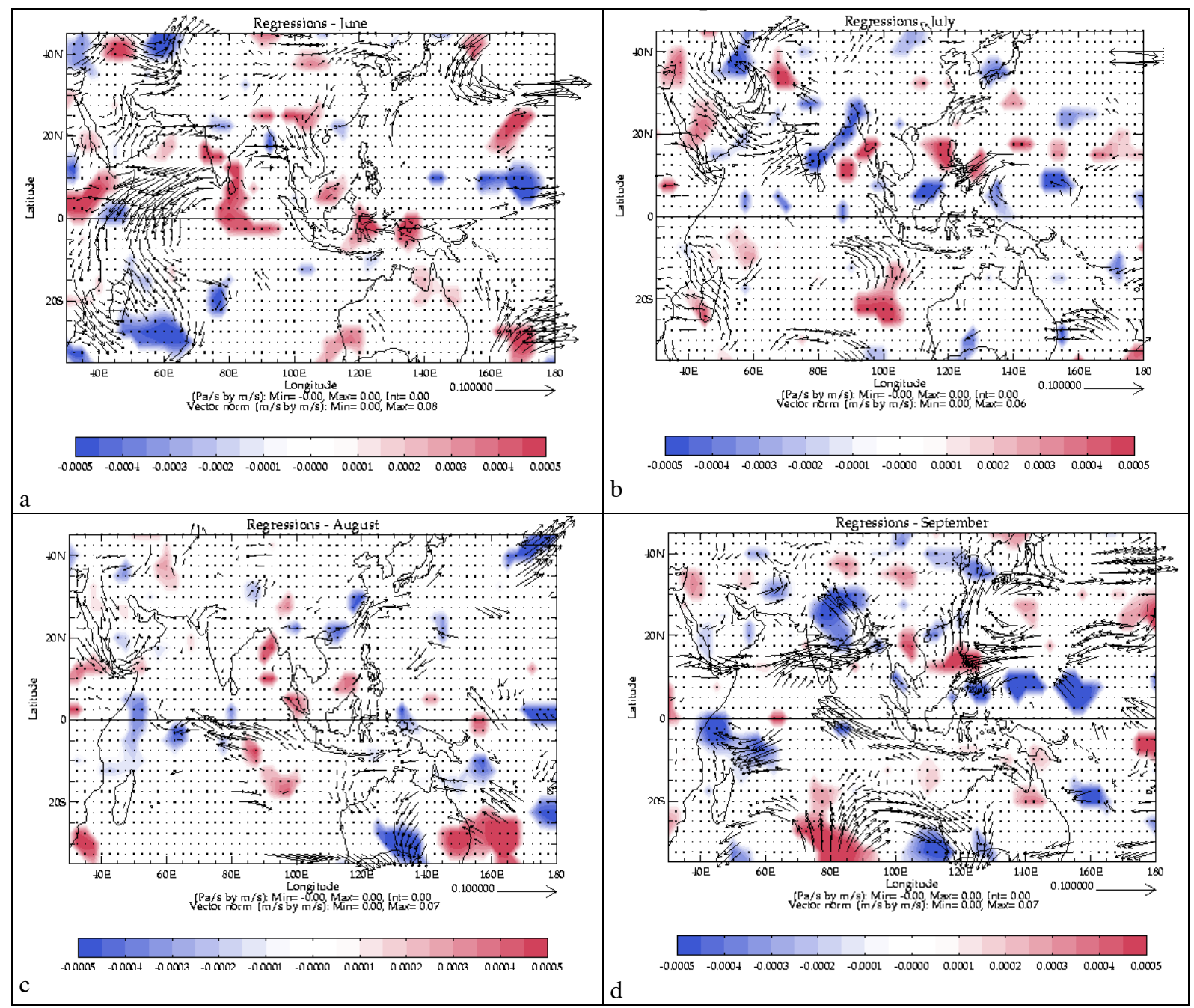

Figure 4. Distribution of monthly regression coefficients of NCEP-R2 $850 \mathrm{hPa}$ wind and 500 hPa vertical velocity versus equatorial zonal winds at $15 \mathrm{hPa}$ in January-February for a) June, b) July, c) August, d) September. Regression coefficients have been computed for the 19792000 period. Maps only show wind vectors and omega values corresponding to regression coefficients above the $90 \%$ confidence level following a phase-scrambling procedure with 999 samples. See text for more details. 
Regressions QBO $15 \mathrm{hPa}(1-2) 200 \mathrm{hPa}$ wind/200 hPa Geopotential height - NCEP2 1979-2000 -

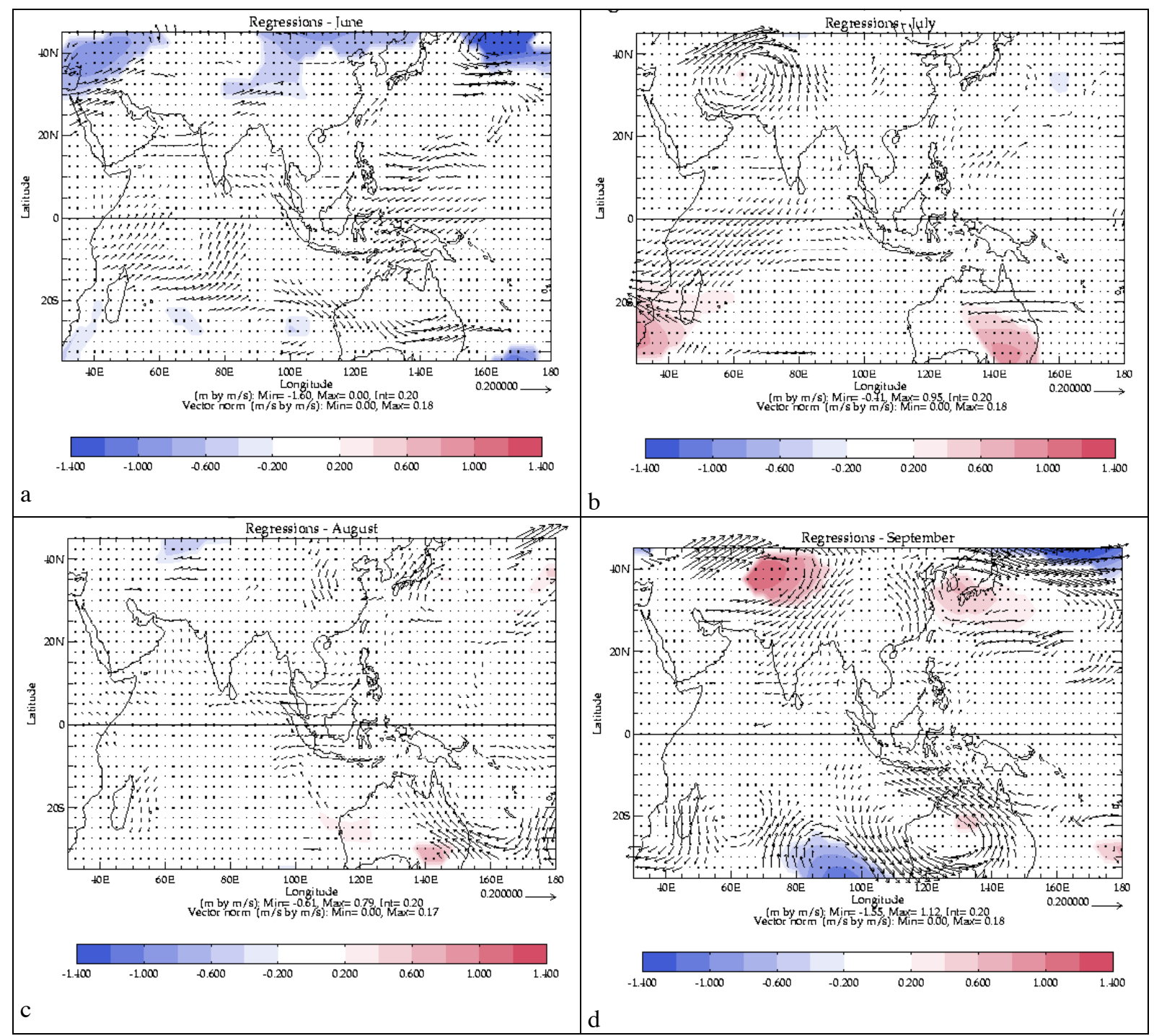

Figure 5. Same as Figure 4, but for the NCEP-R2 $200 \mathrm{hPa}$ wind and geopotential height versus equatorial zonal winds at $15 \mathrm{hPa}$ in January-February. 
Correlations QBO $15 \mathrm{hPa}(1-2) 100 \mathrm{hPa}$ Temperature - NCEP2 1979-2000

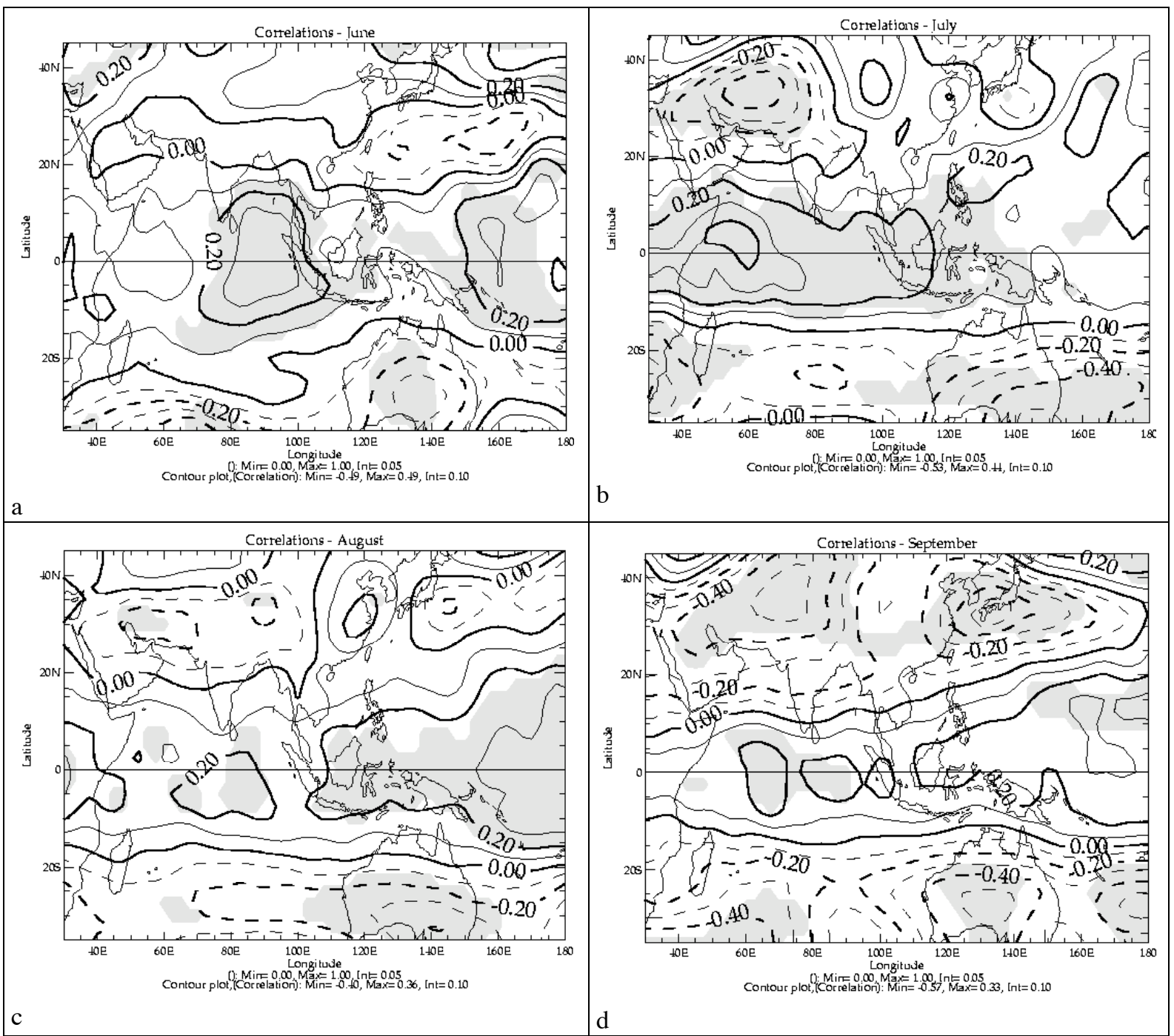

Figure 6. Distribution of monthly correlation coefficients of NCEP-R2 $100 \mathrm{hPa}$ temperature versus equatorial zonal winds at $15 \mathrm{hPa}$ in January-February for a) June, b) July, c) August, d) September. Correlation coefficients have been computed for the 1979-2000 period. Correlation coefficients above the $90 \%$ confidence level following a phase-scrambling procedure with 999 samples are shaded. See text for more details. 
Correlations QBO $15 \mathrm{hPa}(1-2)$ Temp. Trop. - NCEP 1979-2000

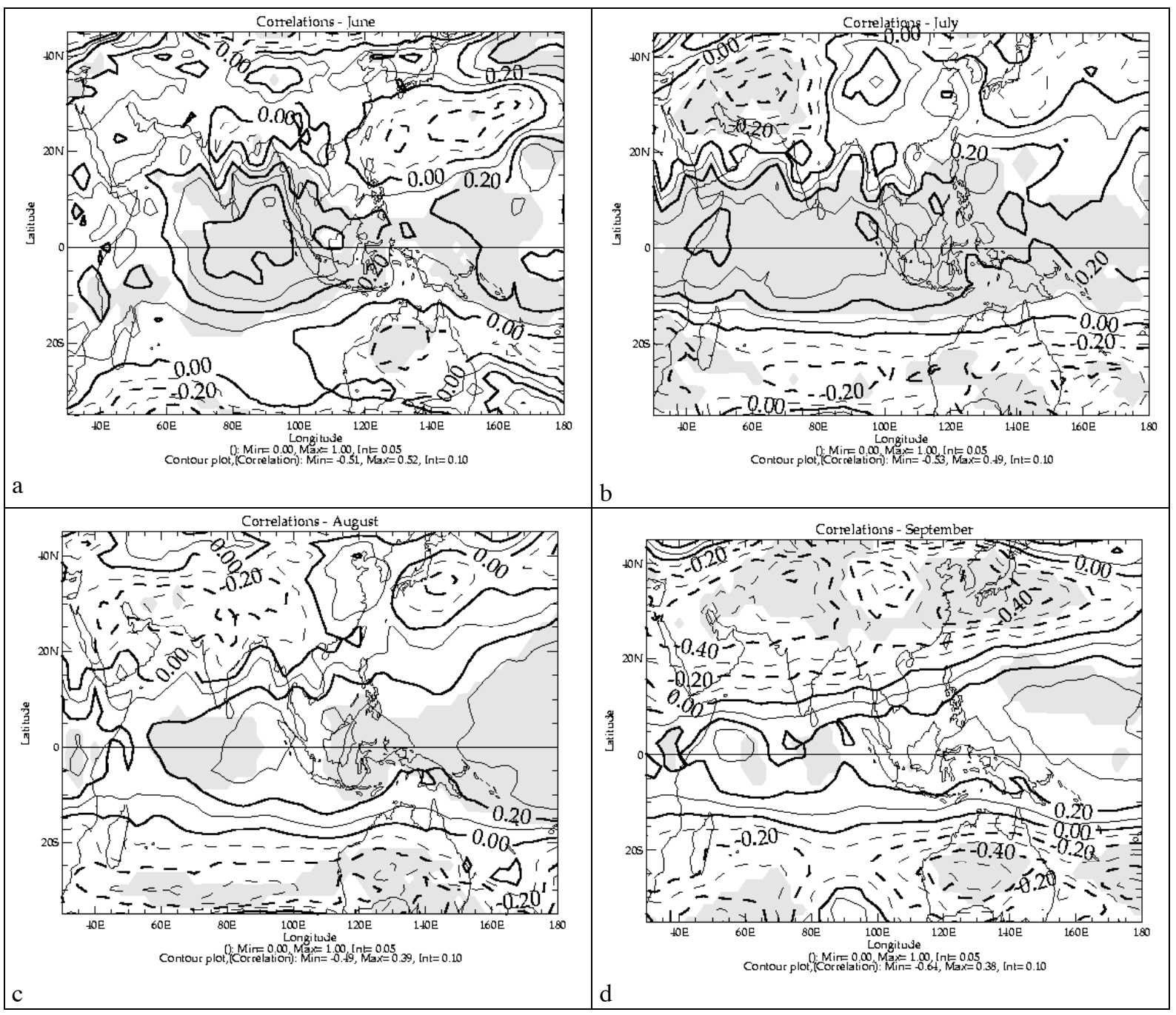

Figure 7. Distribution of monthly correlation coefficients of NCEP tropopause temperature versus equatorial zonal winds at $15 \mathrm{hPa}$ in January-February for a) June, b) July, c) August, d) September. Coefficients have been computed for the 1979-2000 period. Areas with correlation coefficients above the $90 \%$ confidence level following a phase-scrambling procedure with 999 samples are shaded. See text for more details. 
Correlations QBO 15 hPa (1-2) Pres. Trop. - NCEP 1979-2000

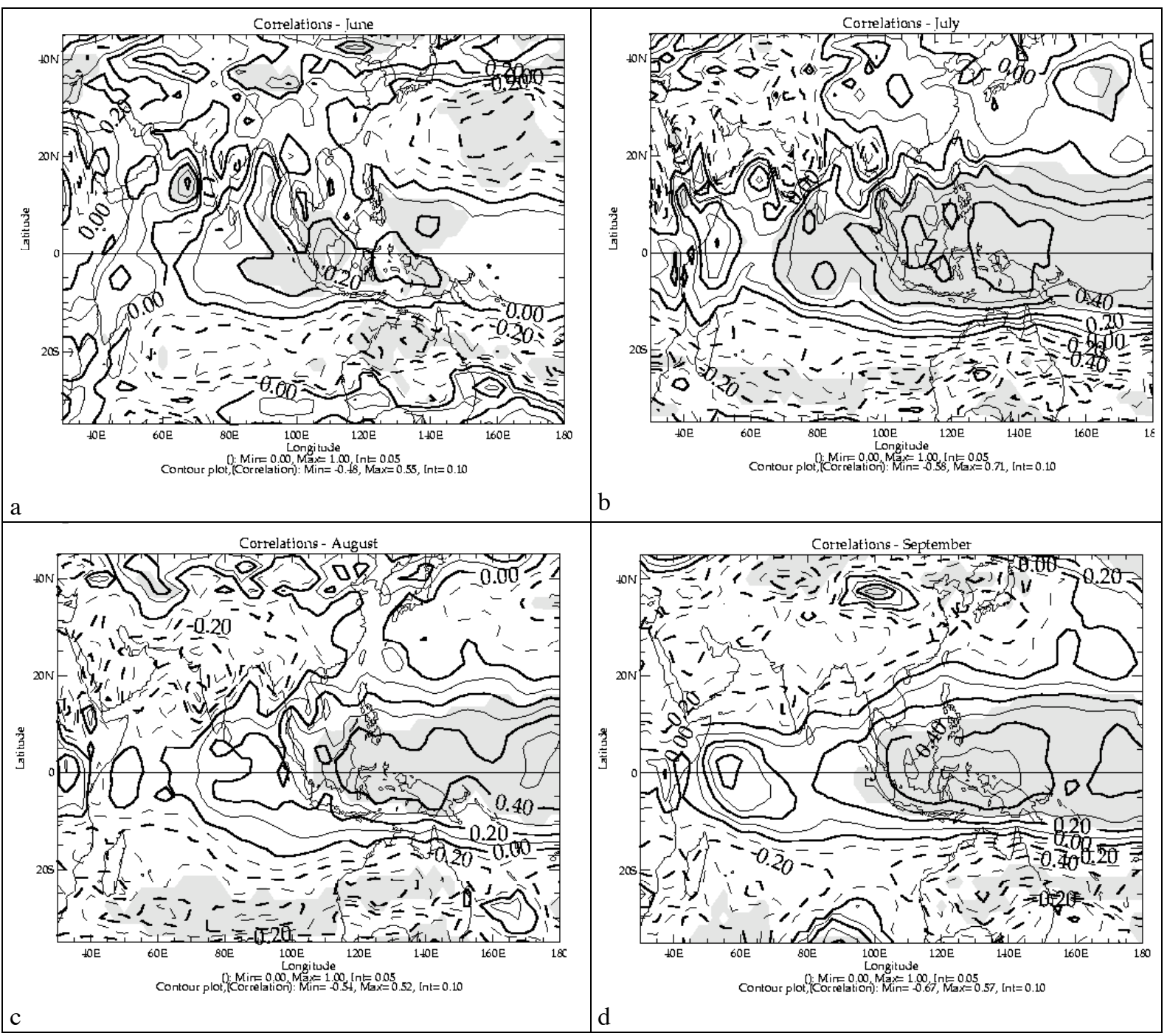

Figure 8. Same as Figure 7, but for the NCEP tropopause pressure versus equatorial zonal winds at $15 \mathrm{hPa}$ in January-February. 


\begin{tabular}{|c|c|c|c|c|c|}
\hline & 40 & 30 & 20 & 15 & 10 \\
\hline JAN & & & $\begin{array}{l}0.314 \\
0.293^{*}\end{array}$ & $\begin{array}{l}0.381 * \\
0.400 * *\end{array}$ & $0.367^{*}$ \\
\hline FEB & & & $\begin{array}{l}0.307 \\
0.266^{*}\end{array}$ & $\begin{array}{l}0.369 * \\
0.375 * *\end{array}$ & $0.333^{*}$ \\
\hline MAR & & & $\begin{array}{l}0.334 * \\
0.282 *\end{array}$ & $\begin{array}{l}0.340 * \\
0.357 * *\end{array}$ & \\
\hline APRIL & & & $\begin{array}{l}0.329 * \\
0.296^{*}\end{array}$ & $\begin{array}{l}0.303 \\
0.333 * *\end{array}$ & \\
\hline MAY & & 0.244 & $0.266^{*}$ & & \\
\hline JUNE & & $\begin{array}{l}0.343 * \\
0.299 *\end{array}$ & & & \\
\hline JULY & $\begin{array}{l}0.318 \\
0.257\end{array}$ & $0.284 * *$ & & & \\
\hline AUG & $\begin{array}{l}0.280 \\
0.277^{*}\end{array}$ & $0.251^{*}$ & & & \\
\hline
\end{tabular}

Table 1. Correlation coefficients for the first 8 months of the year between zonal monthly winds at different stratospheric levels, and the IMR during boreal summer (June until September). Only $90 \%$ and more significant values are reported. The symbol $*(* *)$ denotes a significance larger than $95 \%(99 \%)$. Values in italics correspond to the correlation coefficients between zonal winds and August-September rainfall. 48 years have been considered ( 45 for the $10 \mathrm{hPa}$ level). 
